\title{
THE ROLE OF THE PROMOTIONAL VIDEO "WONDERFUL INDONESIA: A VISUAL JOURNEY" ON BRAND IMAGE AND TOURIST VISITING INTEREST TO WAKATOBI
}

\author{
Herien Natasya Santoso ${ }^{1}$, Christy Widyawati ${ }^{2 \star}$, Rizki Adityaji ${ }^{3}$ \\ 1,2,3 Tourism Department, Faculty of Tourism, Universitas Ciputra Surabaya, Indonesia \\ *Corresponding Author's e-mail: cwidyawati@ciputra.ac.id
}

\begin{abstract}
Wakatobi is a tourist destination that has potentials for remarkable natural beauty. The Indonesian government is also aggressively promoting Wakatobi through the making of the video Wonderful Indonesia: A Visual Journey. However, the tourist visiting rate in Wakatobi is still not very high. Therefore, this study aims to determine the effect of the promotional video on brand image and interest in visiting Wakatobi. This study involved 151 people as samples and the results showed that promotional videos are able to have a positive and significant influence on brand image and tourist visiting interest. Likewise, the brand image is able to provide a positive and significant influence on tourist visiting interest.
\end{abstract}

Keywords: promotional video; visiting interest; brand image; Wakatobi; Wonderful Indonesia

\section{INTRODUCTION}

A tourist attraction will be full of visitors if many people are interested in it. A tourist attraction is in great demand by visitors due to several factors, starting from ODTWA (Obyek dan Daya Tarik Wisata Alam), in english: Natural Tourism Objects and Attractions, prices, facilities and infrastructure, as well as efforts by tourist objects to approach visitors (Firawan \& Suryawan, 2016). Visiting interest is someone's desire to visit an interesting place or area to visit (Putra et al., 2015). Interest in visiting means potential consumers who have never visited and have visited and who are about to visit a tourist attraction (Pradiatiningtyas, 2016). 
Visiting interest can be influenced by brand image; the better the brand image of a product, the more the consumers are interested in buying the product (Ambarwati, 2015). "Brand" and "image" is a single concept, but not identical, "image" in relation to "brand" is considered by consumers as a "general portrait" of the brand object, the quality of the image maker is a planned action of the brand, which will later establish consumer opinion on the brand (Kalieva, 2015). Brand image is the result of observations by consumers regarding the brand as a form of replication of the relationship between brands and consumers that are retained within them (Shabbir et al., 2017). According to Ambarwati (2015), brand image is how consumers see a brand, while brand identity is a method that companies use in launching their brands in the market and consumer perceptions are in line with what the brand wants in the market.

Visiting interest is not only influenced by the brand image, Isman et al. (2020) revealed that a person can be interested in a tourist object that is displayed on a tourism promotion video. In today's digital era, many companies use social media such as Facebook, Youtube as their promotional media by distributing promotional videos publicly (Appel et al., 2020). The promotional video itself is an advertising activity for a product of a brand in order to generate sales. The promotional video has a function as a means of showing the quality of a brand's product so that consumers trust and are interested in the product (Rangaswamy et al., 2020). Tourist objects in a video advertisement are more attractive and proven to generate visitor interest compared to other objects (Lo \& Cheng, 2020). However, a contradictory statement was found. According to Darmawan \& Sanawiri (2018), a tourist spot displayed in a video advertisement or something else does not always get a positive response due to the limited attributes of tourists. Because of these differences, further research is needed.

Išoraitè (2016) states that advertising in mass media (promotional media) creates a brand image and attractiveness for a company or brand. However, previous research by Raghubir \& Corfman (1999) stated that the use of repeated promotions can have a negative effect on the expected product price and the promoted brand image. In Randi's research 
(2016) it is stated that in order to understand and attract consumer interest, a company must have a strong brand image in the minds of consumers. However, it is different from research conducted by Foster (2017) which states that brand image cannot be a tool to predict a person's interest in buying. Because existing research results are still contradictory, further research is needed to get conclusive conclusions.

The promotional video for Wonderful Indonesia itself highlights 4 tourist destinations in Indonesia, namely Banyuwangi, Lombok, Bunaken, and Wakatobi. With more than 2.6 million viewers, the video Wonderful Indonesia: A Visual Journey is able to make viewers attracted by the beauty that is highlighted. This is an evident from the appearance of the many video reactions made by overseas YouTubers. Not a few of these YouTubers want to save money so they can have a vacation in Indonesia. This video reaction evidence shows how important it is for Indonesia to make promotional videos about the beauty of Indonesia.

This research, specifically, only focuses on the Wakatobi content in the video. Wakatobi is one of the tourist attractions that people rarely know but has a very captivating beauty. Wakatobi located in itself is a new tourist spot that has many visitors. Wakatobi located in a district in Southeast Sulawesi Province is a national park area concerning marine biodiversity with the scale and condition of the coral which occupies one of the highest priority positions of marine conservation in Indonesia. Not surprisingly, Wakatobi is famous for its underwater beauty, and has a very beautiful dive spot to visit. Not only the beauty of the sea, Wakatobi has beautiful caves, lakes and beaches with white and fine sand. Apart from its natural beauty, Wakatobi also presents the experience of visiting the Bajo tribe's residence which is not to be missed. In fact, many tourists visit Wakatobi just to find out how the Bajo people carry out their daily routine.

From the above explanation, this study aims to explore the extent to which the promotional video of Wonderful Indonesia, especially those related to the content of the Wakatobi tourist destination, can influence the brand image and interest in visiting tourists. 


\subsection{Hypothesis Development}

Promotion begins with persuasion communication to generate attention and eventually leads to interest in visiting. The form of promotion is not only tourism maps, guidebooks, brochures, leaflets, the internet but also includes organizing events, exhibitions, and performing arts and cultural attractions (Areks et al., 2015). Effective promotion is a promotion that can create and arouse buyer intention. The purpose of promotion according to Kotler \& Armstrong (2018) is to encourage customers to make short-term purchases and improve long-term relationships, advertise products and provide more shelf space. In the context of tourism, targeted promotional activities are better carried out through good communication as well, because communication is an important aspect of marketing the tourism sector. The communication process will later receive a response from the recipient of the message to the community and can affect tourist visits (Indriastuty, 2020).

\section{Hypothesis 1. Promotional video has significant effect on visiting interest}

Advertising or promotion is an effective means of creating a product's brand image in the minds of consumers (Kotler \& Armstrong, 2018). According to Belch et al. (2005), advertising is used to create a brand image and appearance as well as symbolic of a brand, most especially for the brand's ability to sell products or services in which the functional attributes are barely distinguishable. Advertising or promotion is used to differentiate and develop a brand image (Schultz et al., 2013). Promotional activities can develop a brand image which has an important role in determining the attitudes and behavior of consumer in purchasing decisions (Malik et al., 2013). From the explanation above, it can be said that promotions, including in the form of videos, can have an impact on the brand image. One of the promotional functions is to present an impression or image, so it is necessary to make an advertisement by a company to raise a good brand image in the eyes of consumers (Kalieva, 2015).

\section{Hypothesis 2. Promotional video has significant effect on brand image}


Brand image is a social and psychological condition of consumers related to feelings and ideas about a brand, which plays an important role in determining their choice (Kotler \& Armstrong, 2018). According to Mahampang \& Sutrisna (2018), the better the brand image of a company, the more buying interest in the product offered will increase. Brand image is an image that a person has, so that in its implementation, people who have a good perception of the company will generate trust and interest in the company (Adona et al., 2019). With a positive brand image, consumers will determine their choice of buying a product (Dianita \& Arifin, 2018). In the context of the tourism market development, encouraging visitors to pay more attention to brand image is seen as more important than physical products in determining tourist visits (Fariska et al., 2019). The more positive the brand image, the greater the opportunity to increase consumer interest in visiting tourist objects.

\section{Hypothesis 3. Brand image has a significant effect on visiting interest}

\section{METHODS}

\subsection{Sampling and Data Collection}

Purposive sampling technique is used in this research. There are certain criteria in determining the sample: respondents must have watched the video Wonderful Indonesia: A Visual Journey 2016 from the beginning until the end or have accessed the video Wonderful Indonesia: A Visual Journey 2016 through Youtube. The distribution of questionnaires using the google form is carried out online via line, Whatsapp, and Instagram. From the results of the distribution of the questionnaires, 151 questionnaires are suitable for processing. Respondents who participated consisted of $59.6 \%$ female, and $40.4 \%$ male.

\subsection{Measurement}

Promotional videos are measured using 4 measurement items adapted from Teixeira's (2017) research, namely that a video must display interesting content so that the audience is interested and does something real about the video; The videos that are made are similar to 
what is currently circulating on the internet or viral, so that the video is still in touch with what is in the memory of the audience so that it can be meaningful to them. Such videos can stand out and have a positive impact; interesting videos are made with a short duration so as not to be boring for the audience. Videos with very popular soundtracks, displayed in good camera movement, and good video motion can get better feedback on media such as Youtube. Brand image is measured by 3 measurement items in the study of Herr et al. (1994): corporate image, product image, and user image. Finally, visiting interest is measured by 4 measurement items adopted from Ferdinand (2006), namely transactional interest, explorative interest, referential interest, and preferential interest.

\section{RESULT AND DISCUSSION}

Testing the validity and reliability of the model as well as testing the research hypothesis is carried out with the help of the SmartPLS 3.0 software. The requirement to pass the validity test is that the loading factor value must be greater than 0.7 . In the first phase of testing as shown in Table 1, there are three indicators (one indicator in the promotional video construct and two indicators in the brand image construct) that do not meet the requirements, so they must be removed (drop) and will not be included in the next process.

Table 1. Loading Factor of First Stage of Validity Test Results

\begin{tabular}{|c|c|c|c|c|c|}
\hline \multicolumn{2}{|c|}{$\begin{array}{c}\text { Promotional } \\
\text { Video }\end{array}$} & \multicolumn{2}{c|}{ Brand Image } & \multicolumn{2}{c|}{ Visiting Interest } \\
\hline vp1 & .718 & bi 1 & .468 & $\mathrm{mb} 1$ & .846 \\
\hline vp2 & .712 & bi2 & .326 & $\mathrm{mb} 2$ & .836 \\
\hline $\mathrm{vp} 3$ & .697 & $\mathrm{bi} 3$ & .803 & $\mathrm{mb3}$ & .793 \\
\hline $\mathrm{vp} 4$ & .801 & $\mathrm{bi} 4$ & .796 & $\mathrm{mb} 4$ & .838 \\
\cline { 3 - 4 } & & $\mathrm{bi} 5$ & .755 & & \\
\hline
\end{tabular}

After doing the dropping, the process is continued by re-testing the loading factor. The result shows that the second stage of the testing indicates that all indicators have met the requirements of the validity test with a loading factor value greater than 0.7 as shown in Table 2. 
Table 2. Loading Factor of Second Stage of Validity Test Results

\begin{tabular}{|c|c|c|c|c|c|}
\hline \multicolumn{2}{|c|}{$\begin{array}{c}\text { Promotional } \\
\text { Video }\end{array}$} & \multicolumn{2}{c|}{ Brand Image } & \multicolumn{2}{c|}{ Visiting Interest } \\
\hline $\mathrm{vp1}$ & .751 & $\mathrm{bi}$ & .818 & $\mathrm{mb} 1$ & .846 \\
\hline $\mathrm{vp} 2$ & .743 & $\mathrm{bi} 4$ & .819 & $\mathrm{mb}$ & .838 \\
\hline $\mathrm{vp} 4$ & .816 & $\mathrm{bi} 5$ & .819 & $\mathrm{mb3}$ & .794 \\
\cline { 4 - 6 } & & & $\mathrm{mb} 4$ & .834 \\
\hline
\end{tabular}

The composite reliability value in the promotional video construct, brand image and interest in visiting also met the criteria, namely greater than 0.6 . The composite reliability values of the three constructs were consecutively high, namely $0.814,0.897$ and 0.859 (see Table 3). The composite reliability value indicates that the element of validity has been met.

Table 3. Composite Reliability

\begin{tabular}{|l|c|}
\hline & Composite Reliability \\
\hline Promotional Video & .814 \\
\hline Brand image & .859 \\
\hline Visiting interest & .897 \\
\hline
\end{tabular}

In Table 4, it can also be proven that the AVE value of the three constructs is greater than 0.5 so the indicators used in this study have good validity as a measuring tool for each variable.

Table 4. AVE Score

\begin{tabular}{|l|c|c|}
\hline & AVE & VAVE \\
\hline Promotional Video & .594 & .771 \\
\hline Brand image & .670 & .819 \\
\hline Visiting interest & .686 & .828 \\
\hline
\end{tabular}

Another validity test is seen from the Fornell-Larcker criterion value. This method compares the square root of the average variance extracted (AVE) with the latent construct correlation. Therefore, the square root of each AVE construct (Table 5) must have a value greater than the correlation with the other latent constructs. 
Table 5. Fornell-Lacker Criterion

\begin{tabular}{|l|c|c|c|}
\hline & $\begin{array}{c}\text { Promotional } \\
\text { Video }\end{array}$ & Brand Image & Visiting interest \\
\hline Promotional Video & .771 & & \\
\hline Brand image & .455 & .819 & \\
\hline Visiting interest & .581 & .437 & .828 \\
\hline
\end{tabular}

The next test involves measuring internal consistency by noticing the value of Cronbach's alpha and composite reliability $(\mathrm{CR})$, which measures reliability based on the association of the observed variable items. In exploratory research, the value of composite reliability and Cronbach's alpha between 0.60 to 0.70 is acceptable. In Table 6 , the value of composite reliability and Cronbach's alpha is higher than 0.60 so the overall indicators used have fulfilled the element of reliability which is quite good.

Table 6. Cronbach's Alpha \& Composite Reliability

\begin{tabular}{|l|c|c|}
\hline & $\begin{array}{c}\text { Cronbach's } \\
\text { Alpha }\end{array}$ & $\begin{array}{c}\text { Composite } \\
\text { Reliability }\end{array}$ \\
\hline Promotional Video & .657 & .814 \\
\hline Brand image & .757 & .859 \\
\hline Visiting interest & .847 & .897 \\
\hline
\end{tabular}

After the validity and reliability test are passed, the next test is hypothesis testing by looking at the estimated value of the path coefficients, t-statistic and p-value. Based on the results of hypothesis testing in Table 7 , it can be concluded that the three hypotheses proposed in the entire study can be accepted with a p-value $<0.05$ (1-tailed).

Table 7. Hypothesis Testing

\begin{tabular}{|c|c|c|c|c|}
\hline Hypotheses & $\begin{array}{c}\text { Original } \\
\text { Sample }\end{array}$ & $\begin{array}{c}\text { t- } \\
\text { statistic }\end{array}$ & p-value & Note \\
\hline Hypothesis 1 & .217 & 2.791 & .005 & Accepted \\
\hline Hypothesis 2 & .455 & 7.552 & .000 & Accepted \\
\hline Hypothesis 3 & .482 & 6.167 & .000 & Accepted \\
\hline
\end{tabular}

The first hypothesis of this study can be proven that the promotional video variable has a positive and significant effect on visiting interest. Teixeira (2017) states that a tourist attraction in a video advertisement is more attractive and has proven to be able to generate interest in visiting. Through the Wonderful Indonesia video uploaded on the YouTube 
platform through the Indonesia.travel account, many viewers are interested in visiting Wakatobi after watching the video. This video is more about showing the beauty of Wakatobi through a visual context rather than telling a story about Wakatobi in the form of a vlog. Packaged by a supportive soundtrack, it makes the audience even more amazed by the beauty of Wakatobi. Promotional videos are very important in their role to increase interest in visiting Wakatobi, because they show the real situation in Wakatobi, thus making the audience believe in Wakatobi's resources and decide to visit.

The second hypothesis which states that the promotional video variable has a positive and significant effect on the brand image variable can also be accepted. This result contradicts the results of Raghubir \& Corfman's research (1999) which states that repeated promotions can have a negative effect on the brand image being promoted. So this result is in accordance with Teixeira (2017) who states that advertising in mass media (promotional media) can be used to create a brand image and attractiveness for a company or brand. Promotional videos carried out by the Indonesian government, such as via YouTube, while still carrying the slogan "Wonderful Indonesia", are always intensively carried out to attract foreign tourists to visit Indonesia or local tourists to explore other tourist objects. The Indonesian government uses video as a means of promotion. Indonesia uses different video concepts. Starting from vlogging, focusing more on cinematography or the beauty of tourist objects. This is conducted so that the audience is more focused on each tourist attraction resources therefore the audience's perception is more positive about a tourist attraction after watching the video of Wonderful Indonesia. Consequently, promotional videos have a positive and significant effect on the Wakatobi brand image in the video of Wonderful Indonesia where its technique shows more of Wakatobi's natural resources through visuals rather than stories, thus making the audience's perception of Wakatobi's image better.

The final or third hypothesis is also acceptable; that is the brand image variable has a positive and significant effect on the visiting interest variable. This result is in line with Randi's research (2016) which states that to increase consumer interest, a company must have a strong brand image in the minds of consumers. Through the Wonderful Indonesia 
video, the Indonesian government expects tourists to have a better perception of tourist objects, especially in this study, Wakatobi. Through a good brand image and a visual context in the form of a video, it is hoped that Wakatobi will attract the attention of tourists to visit.

\section{CONCLUSIONS}

The result of data processing shows that the promotional video variable is able to provide a positive and significant influence on the brand image and the interest in visiting tourist attractions. Likewise, the brand image is able to provide a positive and significant influence on the interest in visiting tourists. The results of this study can certainly be a reference in disseminating information or knowledge about promotional videos, brand images and visiting interest for further research; as well as video-makers who want to promote certain tourist objects. For further study, it is necessary to examine more deeply about the promotional video variable which is still little study in this variable; it can be related to other variables besides brand image and interest in visiting tourist objects. Researcher is also aware of the shortcomings that exist in this study such as the limited number of samples which may result in a weak element of generalization of the research results. This research also suggests to the government that the video can be focused on one tourist attraction in one video or one video containing only one tourist destination. Moreover, besides being uploaded on YouTube, Wonderful Indonesia videos should also be uploaded on other social media platforms which are currently trending like TikTok.

\section{REFERENCES}

Adona, F., Yusnani, Y., \& Nita, S. (2019). Are Padang city branding shaping audience consciousness: An semiotics analysis of three Padang city branding. Journal Polingua : Scientific Journal of Linguistics, Literature and Education, 7(2), 43-49. https://doi.org/10.30630/polingua.v7i2.73

Ambarwati, M. (2015). Pengaruh citra merek terhadap minat beli (Survei pada mahasiswa 
Universitas Brawijaya yang menggunakan pasta gigi Pepsodent). Jurnal Administrasi Bisnis S1 Universitas Brawijaya, 25(1), 86141.

Appel, G., Grewal, L., Hadi, R., \& Stephen, A. T. (2020). The future of social media in marketing. Journal of the Academy of Marketing Science, 48(1), 79-95. https://doi.org/10.1007/s11747-019-00695-1

Areks, E., Nadjib, M., \& Cangara, S. (2015). Pengaruh penggunaan bauran promosi terhadap tingkat kunjungan wisatawan pada objek wisata alam di Kabupaten Pangkajene dan Kepulauan. Jurnal Komunikasi KAREBA, 4(4), 360-373.

Belch, M. A., Krentler, K. A., \& Willis-Flurry, L. A. (2005). Teen internet mavens: Influence in family decision making. Journal of Business Research, 58(5), 569-575. https://doi.org/10.1016/j.jbusres.2003.08.005

Darmawan, E. W., \& Sanawiri, B. (2018). Dampak video promosi Wonderful Indonesia A Visual Journey through Banyuwangi terhadap perubahan persepsi citra destinasi Banyuwangi. Administrasi Bisnis (JAB), 62(2), 53-61. administrasibisnis.studentjournal.ub.ac.id

Dianita, D. I., \& Arifin, Z. (2018). Pengaruh brand ekstensi dan brand image terhadap minat beli IPhone di Kota Malangv(Survei pada pengunjung Outlet OPPO Smartphone di Mall Plaza Malang). Jurnal Administrasi Bisnis (JAB)/Vol, 64(1), 119-125.

Fariska, I. G. P. P., Mananda, I. G. P. B. S., \& Dewi, N. G. A. S. (2019). Pengaruh brand image terhadap motivasi dan minat wisatawan domestik berkunjung ke Sanur Village Festival. Jurnal IPTA, 7(2), 124. https://doi.org/10.24843/ipta.2019.v07.i02.p03

Ferdinand, A. T. (2006). Metode penelitian Manajemen: Pedoman penelitian untuk penulisan skripsi. In Semarang: Universitas Diponegoro. http://scholar.google.co.id/scholar?q=related:dfd--2JHAEJ:scholar.google.com/\&hl=id\&as_sdt=0,5\#6

Firawan, I. G. N. F., \& Suryawan, I. B. (2016). Potensi daya tarik Wisata Air Terjun Nungnung sebagai daya tarik wisata alam. Jurnal Destinasi Pariwisata, 4(2), 92. https://doi.org/10.24843/jdepar.2016.v04.i02.p15 
Foster, B. (2017). Impact of brand image on purchasing decision on mineral water product "Amidis" (Case study on Bintang Trading Company). American Research Journal of Humanities and Social Sciences, 2(1). https://doi.org/10.21694/2378-7031.16023

Herr, P. M., Aaker, D. A., \& Biel, A. L. (1994). Brand equity and advertising: Advertising's role in building strong brands. Journal of Marketing Research, 31(4), 580. https://doi.org/10.2307/3151889

Indriastuty, N. (2020). Pengaruh bauran promosi terhadap minat pengunjung wisata budaya Pesta Adat Erau. Jurnal Manajemen Komunikasi, 4(2), 61. https://doi.org/10.24198/jmk.v4i2.23264

Isman, I., Patalo, R. G., \& Pratama, D. E. (2020). Pengaruh sosial media marketing, ekuitas merek, dan citra destinasi terhadap minat berkunjung ke tempat wisata. Jurnal Studi Manajemen Dan Bisnis, 7(1), Inpress. https://doi.org/10.21107/jsmb.v7i1.7447

Išoraitè, M. (2016). Raising brand awarenees through internet marketing tools. Independent Journal of Management \& Production, 7(2), 320-339. https://doi.org/10.14807/ijmp.v7i2.391

Kalieva, O. M. (2015). Development of territory brand image: The marketing aspect. Review of European Studies, 7(2), 23-28. https://doi.org/10.5539/res.v7n2p23

Kotler, P., \& Armstrong, G. (2018). Principles of Marketing. In Pearson. Pearson.

Lo, W. H., \& Cheng, K. L. B. (2020). Does virtual reality attract visitors? The mediating effect of presence on consumer response in virtual reality tourism advertising. Information Technology and Tourism, 22(4), 537-562. https://doi.org/10.1007/s40558-020-00190-2 Mahmudah, R. A., \& Sutrisna, E. (2018). Pengaruh iklan dan citra merek terhadap minat beli konsumen pada KFC Metropolitan City Pekanbaru. Jom Fisip, 5(1), 1-12.

Malik, M. E., Ghafoor, M. M., \& lqbal, H. K. (2013). Impact of brand image and advertisement on consumer buying behavior. World Applied Sciences Journal, 23(1), $117-122$.

Pradiatiningtyas, D. (2016). Peran Instagram dalam menarik minat wisatawan berkunjung ke objek wisata Yogyakarta. Jurnal Khasanah IImu, 7(2), 5-24. 
Putra, M. H., Prayanto, \& Yudani, H. D. (2015). Perancangan video promosi street food Semarang untuk mendukung Pariwisata di kota Semarang. Jurnal Dkv Adiwarna, 1(6), 12.

Raghubir, P., \& Corfman, K. (1999). When do price promotions affect pretrial brand evaluations? Journal of Marketing Research, 36(2), 211-222. https://doi.org/10.2307/3152094

Randi. (2016). Pengaruh citra merek terhadap minat beli pada makanan fast food ayam goreng (Studi pada konsumen Texas Chicken Pekanbaru). JOM FISIP.

Rangaswamy, A., Moch, N., Felten, C., van Bruggen, G., Wieringa, J. E., \& Wirtz, J. (2020). The role of marketing in digital business platforms. Journal of Interactive Marketing, 51, 72-90. https://doi.org/10.1016/j.intmar.2020.04.006

Schultz, D. E., Patti, C. H., \& Kitchen, P. J. (2013). The evolution of integrated marketing communications: The customer-driven marketplace. In The Evolution of Integrated Marketing Communications: The Customer-Driven Marketplace (pp. 1-134). https://doi.org/10.4324/9781315872728

Shabbir, M. Q., Khan, A. A., \& Khan, S. R. (2017). Brand loyalty, brand image and brand equity: The mediating role of brand awareness. International Journal of Innovation and Applied Studies, 19(2), 416-423. http://www.ijias.issr-journals.org/

Teixeira, J. M. (2017). The role of promotional touristic videos in the creation of visit intent to Barcelona. International Journal of Scientific Management and Tourism, 3(1), 463-490. 